\title{
Pozitif Psikolojik Sermaye Çalışmaları Üzerine Bir İçerik Analizi
}

\section{Emine Vasfiye KORKMAZ ${ }^{1}$}

Adnan ÇELIK ${ }^{2}$

\begin{tabular}{ccc}
\hline Geliş Tarihi//Received & Kabul Tarihi/ Accepted & Yayın Tarihi/ Published \\
06.05.2021 & 05.07 .2021 & 15.07 .2021 \\
\hline $\begin{array}{l}\text { Citation/Atıf: Korkmaz, E. V. ve Celik, A., (2021), Pozitif Psikolojik Sermaye Çalışmaları } \\
\text { Üzerine Bir İçerik Analizi, Atatürk Üniversitesi İktisadi ve İdari Bilimler Dergisi, 35(3): Sayfa: } \\
\text { 1189-1204, https://doi.org/10.16951/atauniiibd.934028 }\end{array}$ \\
\hline
\end{tabular}

Öz: Pozitif psikolojik sermaye kavramı işletmelerin kurumsal başarıları açısından her geçen gün daha da önemli hale gelmektedir. Bu araştırmanın amacı pozitif psikolojik sermaye alanında hazırlanan lisansüstü tezlere ilişkin farklı disiplinlerde yapılan araştırmaları, yöntemleri, ele alınan değişkenleri ve tezlerde yer alan neden sonuçlara ilişkin bilgileri ortaya koymaktır. Bu kapsamda YÖK Ulusal Tez Merkezinde yer alan 123 lisansüstü tez içerik analizi yöntemiyle incelenmiştir. Türkiye'de 34 ilde, 58 üniversitede yüksek lisans ve doktora tezi hazırlanmıştır. En çok Marmara Üniversitesi ve Çanakkale Üniversitesinde bu alanda çalışma yapılmıştır. En çok işletme ve psikoloji konularında çalışmalar yapılmıştır. Çalışmaların en çok öğretmenler $(\mathrm{n}=10656)$ üzerine uygulandığ belirlenmiştir. Araştırmalarda bağımlı değişken olarak en çok iş tatmini ( $\mathrm{n}=6)$, örgütsel bağl1lı $(\mathrm{n}=5)$ ve çalışan performansı değişkenlerinin; bağımsız değişken olarak ise en çok cinsiyet $(n=71)$, çalışma süresi-deneyim $(n=67)$ ve eğitim $(n=67)$ değişkenlerinin kullanıldığı sonucuna ulaşılmıştır.

Anahtar Kelimeler: Pozitif Psikolojik Sermaye, Pozitif Psikoloji, Yönetim, İçerik Analizi

\section{A Content Analysis on Positive Psychological Capital Studies}

Abstract The concept of positive psychological capital is becoming more and more important for the corporate success of businesses. The aim of this study is to reveal the researches conducted in different disciplines related to the postgraduate theses prepared in the field of positive psychological capital, its methods, the variables discussed and the information about the cause and effect in the theses prepared. In this context, 123 graduate theses in YÖK National Thesis Center were analyzed by content analysis method. Master's and doctoral dissertations were prepared in 34 provinces and 58 universities in Turkey. Most studies were conducted by Marmara University and Çanakkale University in this field. Most studies have been conducted on business and psychology. It was determined that the studies were mostly applied on teachers $(n=10656)$. As the dependent variable in the studies, job satisfaction $(n=6)$, organizational commitment $(n=$ 5) and employee performance variables; As independent variables, it was concluded that the variables of gender $(n=71)$, working time-experience $(n=67)$ and education $(n=67)$ were mostly used.

Keywords: Positive Psychological Capital, Positive Psychological, Management, Content Analysis

Jel Codes: 015, D23, M12

1 Dr. Öğr. Üyesi, İskenderun Teknik Üniversitesi, İşletme ve Yönetim Bilimleri Fakültesi, EkonomiBölümü, emine.korkmaz@iste.edu.tr, https://orcid.org/0000-0001-7202-6849

${ }^{2}$ Prof. Dr., Selçuk Üniversitesi, İktisadi ve İdari Bilimler Fakültesi, İşletme Bölümü, adnancelik@selcuk.edu.tr,https://orcid.org/0000-0002-8538-9937 


\section{EXTENDED SUMMARY}

\section{Research Problem:}

The concept of positive psychological capital is becoming more and more important for the corporate success of businesses. The purpose of this research is to reveal the researches, methods, variables dealt with in different disciplines related to the postgraduate theses prepared in the field of positive psychological capital and the information about the cause and effect in the theses prepared.

\section{Research Questions:}

The basic questions aimed to be answered by the study; Which disciplines deal with the issue of positive psychology, the methods used in the studies, what the dependent and independent variables are studied together with positive psychology, and lastly, how the cause and effect relationships are shaped in the studies on this subject in these theses.

\section{Literature Review:}

The presence of employees who are satisfied with their job, have developed psychological resilience, are optimistic, have a high level of self-efficacy, and have the hope that their expectations will be met in their institution will increase the positive psychology environment in organizations. Therefore, the concept of positive psychological capital is important in institutions. The investigated studies show that the issue of positive psychology has started to be discussed more and more every day in social sciences.

\section{Methodology:}

In this study, which was created with the information obtained from the graduate thesis documents downloaded from the National Thesis Center, content analysis was used as a method. Content analysis, which first started with the examination of newspapers in the 16th century, is a method that is widely used in many disciplines today (Çilingir, 2017: 149).

Results and Conclusions:

According to the research results, the most used keyword in thesis studies is teacher. The city with the highest number of graduate theses on positive psychological capital is Istanbul, Marmara University and Çanakkale University are the universities with the highest number of theses. Most of the theses on the subject were prepared in the Institute of Social Sciences and mostly in the field of business administration. The first thesis on the subject was done in 2011, and the most work was done in 2019. Most used analysis methods in studies; Cronbach Alpha value is correlation and $t$ test. According to the results of the research, the biggest sample group is teachers and then white-collar employees. With the issue of positive psychological capital, the most; job satisfaction, then organizational commitment, employee performance, organizational performance management, burnout and commitment dependent variables are discussed. When we look at the independent variables; the subject was mostly explored with the gender independent variable. Then, working time-experience, education, age, marital status and status-titleposition were discussed with independent variables. 


\section{Giriş}

Günümüzde üretim faktörlerinden en önemlisi haline gelen beşeri sermayenin, işletmeler açısından taşıdığı önem, her geçen gün artmaktadır. İşletmelerin kâr elde etme, sürdürülebilir bir marka oluşturma, topluma fayda sağlama gibi kendi genel amaçları doğrultusunda sağlam adımlarla ilerleyebilmeleri, büyük oranda çalışanlarının performansına bağlıdır. Çalışanların performansının artması da, emek verdikleri işletmelerden iyi bir maaş, sosyal güvence, kariyer basamaklarında ilerleyebilme gibi özel amaçlarının gerçekleşebilme durumu ile ilgilidir. Bir örgütte bireysel ve kurumsal amaçların ortak yürütülmesi örgütsel memnuniyeti arttırır.

İşinden memnun, psikolojik dayanıklılı̆̆ 1 gelişmiş, iyimser, öz yeterlilik düzeyi yüksek, çalıştığı kurumda beklentilerinin karşılanacağına dair umudu olan çalışanların varlığı, örgütlerde pozitif psikoloji ortamını yükseltir. $\mathrm{Bu}$ nedenle kurumlarda pozitif psikolojik sermaye kavramı önemlidir. İncelenen çalışmalar göstermektedir ki son zamanlarda sosyal bilimlerde, pozitif psikoloji konusu her geçen gün daha fazla ele alınmaya başlamıştır. Bu nedenle, bu çalışma Türkiye'de pozitif psikolojik sermaye konusunda hazırlanan tezlere ilişskin araştırma detaylarını ve sonuçlarını incelemek üzere hazırlanmıştır. Araştırmanın veri kaynağı, Ulusal Tez Merkezinden elde edilen lisansüstü tezlerden oluşmuştur.

\section{Literatür Taraması}

Günümüzde önemli bir kaynak haline gelen örgüt bireyinin duygu ve düşüncelerinin, psikolojisinin, moralinin, motivasyonel yüksekliğinin, kurumsal başarıya etkisi pek çok çalışma ile ortaya konulmuştur. Özellikle ikinci dünya savaşının insanlar üzerinde fiziksel ve psikolojik anlamda yarattığı negatif etki, savaş sonrası psikoloji alanında yapılan çalışmaların artmasına neden olmuştur. Psikolojinin 1950'li yıllardan sonra insanları iyileştirici etkisinin farkındalığ artmıştır (Tösten, 2015: 16). Maslow "Motivasyon ve Kişilik" isimli çalışmasında, neden bazı insanların güzellikleri algılarken diğerlerinin algılayamadığını, sağlıklı insanların gerçekliği daha etkili bir şekilde algılamasına, geleceği daha doğru bir şekilde tahmin etmesine izin veren faktörlerin önemini pozitif psikoloji yaklaşımının doğuşu sürecinde ele almıştır (Maslow, 1954: 282). Pozitif psikoloji kavramı, Martin Seligman tarafindan, insanların daha iyi, daha olumlu, daha başarılı hallerinin önemini vurgulamak adına ilk defa 1999 yılında ele alınmıştır (Linley vd., 2006). Bir bireyin; 1) Zor olan görevlerle mücadelede başarılı olması için gereken çabayı üstlenmesi konusunda kendine güvene (öz-yeterlik) sahip olması; 2) Şimdi ve gelecekte başarılı olabilmesi konusunda olumlu öngörüsünün olması (iyimserlik); 3) Hedeflere ulaşmak için sebat edebilme (umut); 4) Zorluklarla mücadele edilen zamanlarda, başarıya ulaşmak için gerekli esnekliğe sahip olma gibi özellikleriyle tasvir edilen olumlu psikolojik gelişim, pozitif psikoloji olarak tanımlanmaktadır (Luthans vd., 2007: 3). Kurum içerisinde psikolojik 
sermayenin bazı durumlarla pozitif bazı durumlarla negatif bir ilişkisi olduğu söylenebilir. Genel olarak psikolojik sermayenin negatif ilişkisi olduğu durumlar yani: yani psikolojik sermaye arttıkça azalan durumlar; işten ayrılma niyeti, örgütsel sinizm ve tükenmişlik gibi durumlardır. Bu nedenle örgütlerde liderler veya insan kaynakları yöneticileri parasal veya fiziksel sermaye unsurları gibi psikolojik sermayeye de yatırım yapmaları yaşanabilecek problemlerin üstesinden gelmede rekabet koşullarında önemli bir güç sağlayacaktır (Sağır, 2020: 570).

Pozitif psikoloji konusu ile ilgili bilimsel raporlar, makaleler, tezler dünya çapında literatüre sunulmaya devam etmektedir. Son yıllarda Türkiye'de de pozitif psikoloji kavramı üzerine lisansüstü tezler başta olmak üzere pek çok bilimsel araştırma yapılmaya devam etmektedir. Bu araştırma ile Türkiye'de pozitif psikoloji konusu hakkında yayınlanan doktora ve yüksek lisans tezleri kapsamında konunun ele alınması ve hazırlanan tezlerde ortaya konulan sonuçların ve katkıların değerlendirilerek gelecekte yapılacak çalışmalara yol gösterilmesi amaçlanmıştır. Çalışmada, Türkiye'de pozitif psikoloji konusunda hazırlanan lisansüstü tezler, Yüksek Öğretim Kurulu Başkanlığının (YÖK) sitesinde yer alan Ulusal Tez Merkezinden derleme yöntemi ile sağlanmıştır. Elde edilen veriler, içerik analizi yöntemi ile değerlendirilmiştir.

\section{Araștırmanın Yöntemi}

Ulusal Tez Merkezinden indirilen lisansüstü tez dokümanlarından alınan bilgiler ile oluşturulan bu çalışmada, içerik analizi yöntemi tercih edilmiştir. İlk olarak gazetelerin incelenmesi ile 16. yüzyılda başlayan içerik analizi, günümüzde birçok bilim dalında yararlanılan bir yöntemdir (Çilingir, 2017: 149). Belgelerden röportaj kayıtlarına, medya ürünlerinden, kişisel röportajlara kadar her türlü yazılı materyalle içerik analizi yapılabilmektedir. İçerik analizini doğası gereği büyük miktarlarda metni sistematik kurallara dayalı analiz etmek için kullanılabilir. Çünkü bu analiz yönteminde bilgisayar destekli analizlerin yapılmasına imkân vardır (Cohen vd., 2007: 475).

\section{Araştırmanın Amacı ve Önemi}

Örgüt ortamındaki bireylerin daha iyi, daha olumlu ve daha başarılı hallerini destekleyen pozitif psikoloji kavramına ilişkin bilincin artması, kurumlarda olumlu bir örgüt ikliminin oluşması önemlidir. Araştırmalar göstermektedir ki, bu bilinci arttırmak örgüt çalışanlarının motivasyonlarını arttıracağ 1 gibi, performans, verimlilik, iş tatmini, işe adanmışlık gibi önemli konuları da etkileyeceği için, kavram irdelenmesi gereken önemli bir konudur.

Yapılan çalışma ile cevaplandırılması amaçlanan temel sorular; pozitif psikoloji konusunun hangi disiplinlerde ele alındığı, çalışmalarda kullanılan yöntemler, pozitif psikoloji ile birlikte çalışılan bağımlı ve bağımsız değişkenlerin neler olduğu ve son olarak bu tezlerde bu konuda yapılan çalışmalardaki neden sonuç ilişkilerinin nasıl şekillendiğidir. 


\section{Araştırmanın Bulguları}

İçerik analizi yöntemi ile ulaşılan lisansüstü tezler, Ulusal Tez Merkezi veri tabanından "pozitif psikolojik sermaye" anahtar sözcügüü ile taranarak elde edilmiş ve toplam 124 teze ulaşılmıştır. Yazarlar tarafından erişime izin verilmeyen bir tez örneklem dışında bırakılarak, 123 adet lisansüstü tez araştırmada kullanılmıştır. İncelemeye dâhil edilen lisansüstü tezlerin 37'si doktora, 86's1 yüksek lisans tezidir. Yıllar itibari ile tezlerin dağılımına bakıldığında; pozitif psikoloji hakkında hazırlanan ilk lisansüstü tezin 2011 yılında yazıldığı, konunun en çok ele alındığ yılın 2019 yılı olduğu en fazla işletme $(\mathrm{n}=48)$ alanında lisansüstü tez hazırlandığı sonucuna ulaşılmıştır.

\subsection{Pozitif Psikolojik Sermaye Konusunda Hazırlanan Tezlerde} Kullanılan Anahtar Kelimelere İlişkin Bulgular

Bilimsel araştırmalarda seçilen anahtar kelimeler, araştırmanın ana fikri ve kullanılan yöntemleri hakkında bilgi veren önemli kavramlardır. $\mathrm{Bu}$ çalışmada incelenen 86's1 yüksek lisans 37'si doktora olmak üzere toplam 123 lisansüstü tezin anahtar kelimeleri ele alınmıştır. Tezlerde pozitif psikoloji ve pozitif psikolojik sermaye dışında toplamda 202 farklı anahtar kelimeye yer verildiği sonucuna ulaşılmıştır. Pozitif psikolojik sermaye $(n=87, \% 42,6)$ ve pozitif psikoloji $(\mathrm{n}=35, \% 17,1)$ 'den sonra en çok kullanılan anahtar kelime öğretmendir $(\mathrm{n}=16, \% 7,8)$. Çalışmalarda kullanılan diğer anahtar kelimelerin bazıları; psikolojik sermaye $(\mathrm{n}=14, \% 6,8)$, örgütsel bağl1lı $(\mathrm{n}=12, \% 5,8)$, umut $(\mathrm{n}=10, \% 4,9)$, öz yeterlilik $(\mathrm{n}=10, \% 4,9)$, pozitif örgütsel davranış $(\mathrm{n}=10$, $\% 4,9)$, iyimserlik $(\mathrm{n}=9, \% 4,4)$, dayanıklılı $(\mathrm{n}=9, \% 4,4)$, iş tatmini $(\mathrm{n}=9, \% 3,4)$, iyi oluş ( $\mathrm{n}=7, \% 4,4)$, tükenmişliktir $(\mathrm{n}=6, \% 2,9)$.

\subsection{Pozitif Psikolojik Sermaye Konusunda Hazırlanan Tezlerin} Hazırlandığı Birimlere Dair Bulgular

Tablo 1'de Ulusal Tez Merkezi veri tabanından indirilen tezler, hazırlandıkları üniversitelere göre ele alındığında; Türkiye'de 34 ildeki 58 üniversitede yani illerin $\% 41,9$ 'unda üniversitelerin $\% 28,1$ 'inde pozitif psikolojik sermaye üzerine en az bir tez yazılmıştır. Pozitif psikolojik sermaye konusuna ilişkin en fazla lisansüstü araştırmanın yapıldığı il İstanbul $(n=42)$, en fazla tezin yazıldığı üniversiteler aynı sayıda olan Marmara Üniversitesi $(n=8)$ ve Çanakkale Üniversitesidir $(\mathrm{n}=8)$.

Tablo 1. Lisansüstü Tezlerin Hazırlandıkları Üniversitelere Göre Dă̆ılımı

\begin{tabular}{|l|c|c|c|l|c|c|c|}
\hline Üniversite Adı & YL & Dr & Toplam & Üniversite Adı & YL & Dr & Toplam \\
\hline $\begin{array}{l}\text { Abant İzzet } \\
\text { Baysal }\end{array}$ & 2 & 1 & 3 & İstanbul Arel & 2 & 2 & 4 \\
\hline Afyon Kocatepe & 1 & - & 1 & İstanbul Gelişim & 1 & 1 & 2 \\
\hline $\begin{array}{l}\text { Alanya Alâeddin } \\
\text { Keykubat }\end{array}$ & 1 & - & 1 & $\begin{array}{l}\text { İstanbul Sebahattin } \\
\text { Zaimoğlu }\end{array}$ & 1 & - & 1 \\
\hline Amasya & 1 & - & 1 & İstanbul Ticaret & 1 & - & 1 \\
\hline Anadolu & 2 & 1 & 3 & İnönü & 1 & - & 1 \\
\hline
\end{tabular}


Pozitif Psikolojik Sermaye Çalışmaları Üzerine Bir İçerik Analizi

Tablo 1 Devamı. Lisansüstü Tezlerin Hazırlandıkları Üniversitelere Göre Dağılımı

\begin{tabular}{|l|c|c|c|l|c|c|c|}
\hline Ankara & 2 & 1 & 3 & $\begin{array}{l}\text { Karamanoğlu } \\
\text { Mehmet Bey }\end{array}$ & 1 & - & 1 \\
\hline Atatürk & 2 & 1 & 3 & Kars Kafkas & 3 & - & 3 \\
\hline Bahçeşehir & 4 & - & 4 & Kocaeli & 1 & - & 1 \\
\hline Balıkesir & - & 1 & 1 & Maltepe & 1 & - & 1 \\
\hline Beykent & 2 & - & 2 & Marmara & 4 & 4 & 8 \\
\hline $\begin{array}{l}\text { Bilecik Şeyh } \\
\text { Edebali }\end{array}$ & 1 & - & 1 & Mersin & - & 1 & 1 \\
\hline $\begin{array}{l}\text { Burdur Mehmet } \\
\text { Akif Ersoy }\end{array}$ & 1 & - & 1 & Necmettin Erbakan & 1 & - & 1 \\
\hline Bursa Uludağ & 2 & - & 2 & Nişantaş1 & 1 & - & 1 \\
\hline Çağ & 2 & 1 & 3 & Pamukkale & 1 & - & 1 \\
\hline Çanakkale & 7 & 1 & 8 & $\begin{array}{l}\text { Recep Tayyip } \\
\text { Erdoğan }\end{array}$ & 2 & - & 2 \\
\hline Çukurova & 1 & - & 1 & Sakarya & 2 & 2 & 4 \\
\hline Dokuz Eylül & 6 & - & 6 & $\begin{array}{l}\text { Sakarya Uygulamalı } \\
\text { Bilimler }\end{array}$ & - & 1 & 1 \\
\hline Dumlupınar & 1 & 1 & 2 & Selçuk & - & 1 & 1 \\
\hline Erciyes & - & 2 & 2 & Siirt & 3 & - & 3 \\
\hline Erzincan & - & 1 & 1 & Süleyman Demirel & 1 & 1 & 2 \\
\hline $\begin{array}{l}\text { Eskişehir } \\
\text { Osmangazi }\end{array}$ & 1 & - & 1 & Tokat Gaziosmanpaşa & - & 1 & 1 \\
\hline Fatih & 1 & - & 1 & Toros & 1 & - & 1 \\
\hline Gazi & 1 & - & 1 & Türk Hava Kurumu & 1 & - & 1 \\
\hline Gaziantep & 1 & 4 & 5 & Ufuk & 1 & - & 1 \\
\hline Gebze Teknik & - & 1 & 1 & Uşak & 1 & - & 1 \\
\hline Hacettepe & - & 1 & 1 & Üsküdar & 1 & - & 7 \\
\hline Haliç & 2 & - & 2 & Yalova & - & 1 \\
\hline İbn Haldun & 1 & - & 1 & Yildı Teknik & - & 1 \\
\hline İstanbul & 1 & 5 & 6 & $\begin{array}{l}\text { Zonguldak Bülent } \\
\text { Ecevit }\end{array}$ & - & 1 \\
\hline$*$ YL= Yüksek Lisans & $* \mathrm{D}=$ Doktora & TOPLAM & 86 & 37 & 123 \\
\hline
\end{tabular}

Veri tabanlarından elde edilen bilgiler doğrultusunda Grafik 1'de görüldügü üzere pozitif psikolojik sermaye konusu üzerine hazırlanan tezlerin \%74,8'lik büyük bir kısmı Sosyal Bilimler Enstitüsü (n=92) bünyesinde hazırlanmıştır. Ardından \%18,7'si Eğitim Bilimleri Enstitüsü $(n=23)$, \%4,1’i Lisansüstü Eğitim Enstitüsü (n=5), \%1,6'sı İşletme Enstitüsü (n=2) ve \% 0,8'i Sağlık Bilimleri Enstitüsünde $(\mathrm{n}=1)$ hazırlanmıştır. Pozitif psikolojik sermaye konusunda işletme anabilim dalı $(\mathrm{n}=48) \% 39$ ile en fazla tez çalışmasının yapıldığı alandır. Ardından eğitim bilimleri anabilim dalı $(n=26, \% 21)$, psikoloji $(\mathrm{n}=8, \% 6,5)$, klinik psikoloji $(\mathrm{n}=8, \% 6,5)$ ve felsefe ve din bilimleri anabilim dalı $(\mathrm{n}=6, \% 4,9)$ gibi çalışma alanları gelmektedir. 


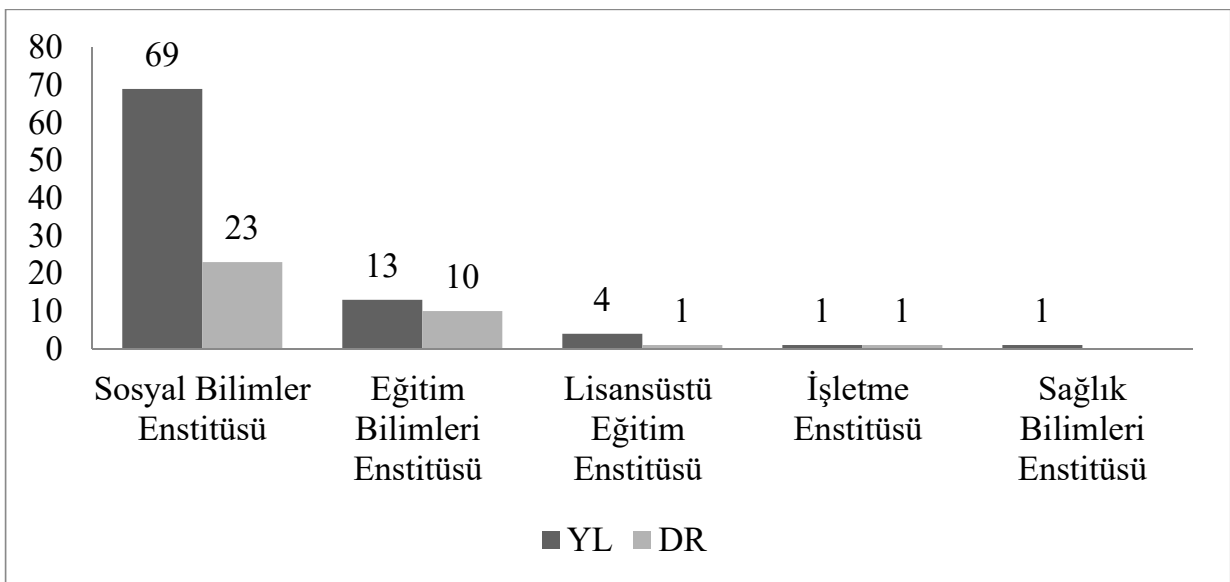

Grafik 1. Yillara Göre Dă̆llım

5.3. Pozitif Psikolojik Sermaye Konusunda Hazırlanan Tezlerin Yapıldiğ Ylllara Ait Bulgular

Grafik 2'ye baktığımızda, pozitif psikolojik sermaye konusu üzerine ilk tezin hazırlandığı 2011 yılında, 1 adet yüksek lisans ve 1 adet doktora tezi hazırlanmıştır. 2012 yılında herhangi bir lisansüstü tez hazırlanmadığı, en fazla çalışmanın 26 yüksek lisans ve 11 doktora tezi ile 2019 yılında yapıldığ sonucuna ulaşı1mıştır.

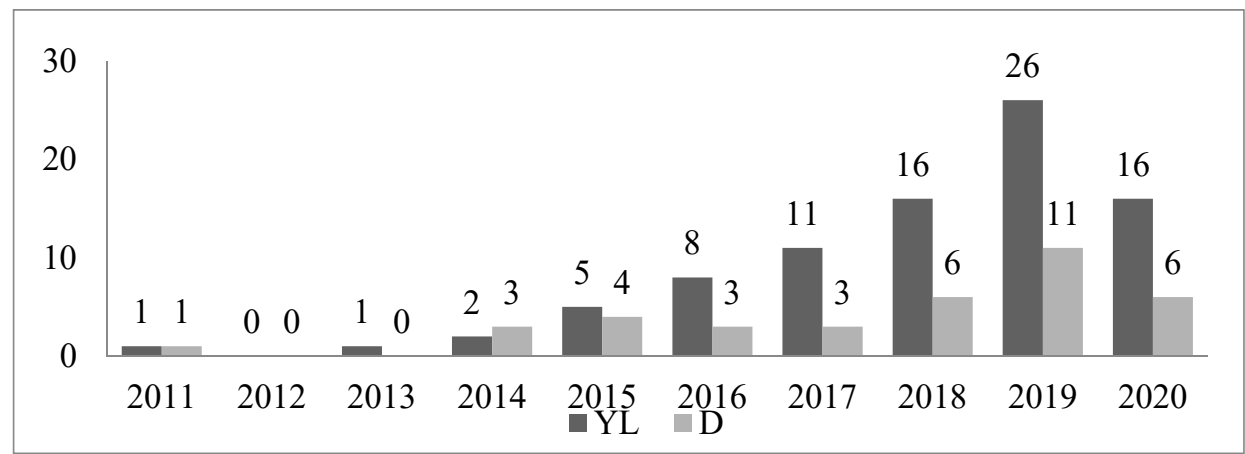

Grafik 2. Lisansüstü Tezlerin Hazırlandıkları Yıllara İlişkin Dă̆ılımı

5.4. Ulusal Tez Merkezinde Pozitif Psikoloji Konusunda Hazırlanan Lisansüstü Tezlere İlişkin Araştırma ve Veri Analiz Yöntemlerine İlişkin Bulgular

Lisansüstü tezlerde kullanılan araştırma yöntemlerinin dağılımına incelediğimizde; Ulusal Tez Merkezinde yer alan 123 lisansüstü tezin 107'si nicel araştırma, 9 tanesi nitel araştırma ve 7 tanesi de karma yöntem kullanılarak hazırlanmıştır. En fazla kullanılan veri toplama aracı ankettir. 
Ulusal Tez Merkezi veri tabanından elde edilen bilgilere göre, Grafik 3'de görüldüğü üzere; çalışmaların çoğunda yani \%85,3'ünde $(n=105)$ cronbach alpha analizi yapılmıştır. Ardından en fazla kullanılan yöntemlerin bazıları; $\% 79,6$ ile $(\mathrm{n}=98)$ korelasyon, \%69,1 ile $(\mathrm{n}=85)$ t testi, \%61,7 ile $(\mathrm{n}=76)$ ANOVA ve $\% 57,7$ ile $(n=71)$ regresyon yöntemidir.

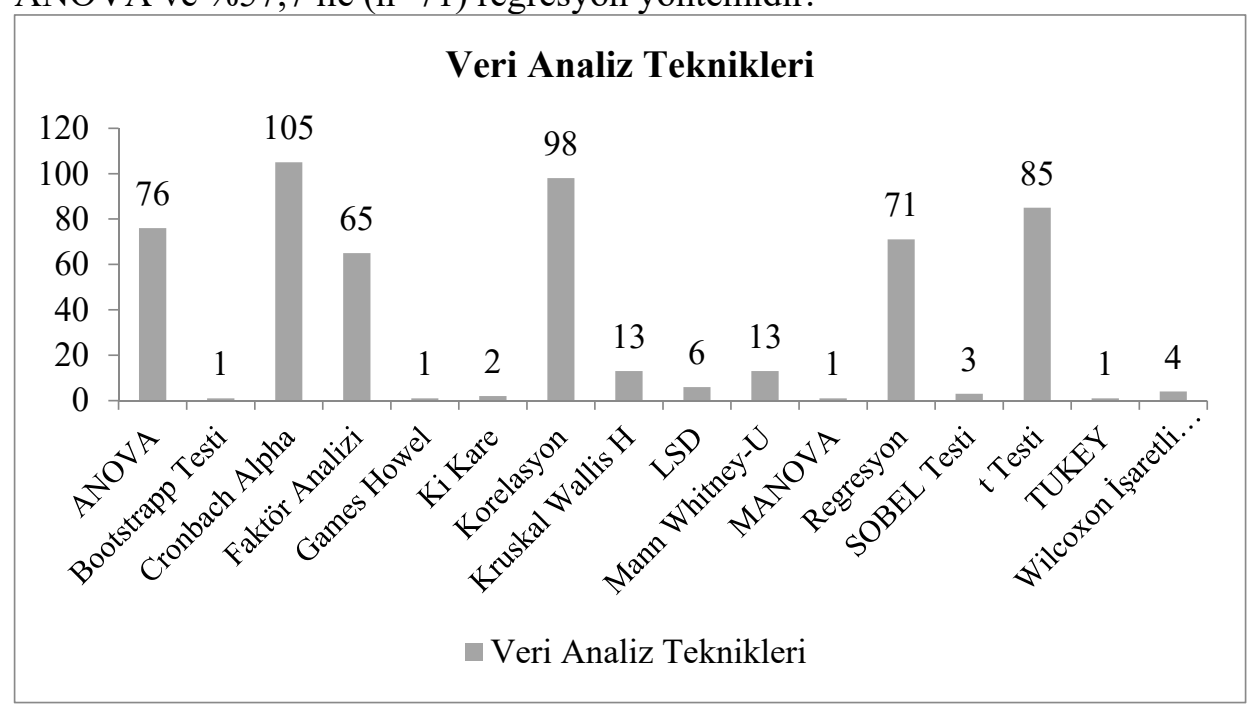

Grafik 3. Lisansüstü Tezlerin Veri Analiz Yöntemleri

5.5. Ulusal Tez Merkezi Veri Tabanında Pozitif Psikolojik Sermaye Konusu Üzerine Hazırlanan Tezlerin Örneklem Büyüklüklerine İlişkin Bulgular

Grafik 4'de veri tabanındaki tezlerden elde edilen bilgilere örnek büyüklüğüne ilişkin bulgular yer almaktadır. $\mathrm{Bu}$ sonuçlara göre en fazla araştırma uygulanan örneklem grubu öğretmenlerdir $(\mathrm{n}=10.656)$. Öğretmenlerin ardından konuya ilişkin en fazla uygulama yapılan örneklem gruplarının başında; beyaz yakalı idari personeller $(n=6946)$, sağlık sektörü çalışanları $(\mathrm{n}=6613)$, turizm sektörü çalışanları $(\mathrm{n}=4700)$, üniversite öğrencileri $(\mathrm{n}=3065)$ ve akademisyenler $(\mathrm{n}=2592)$ gelmektedir. 


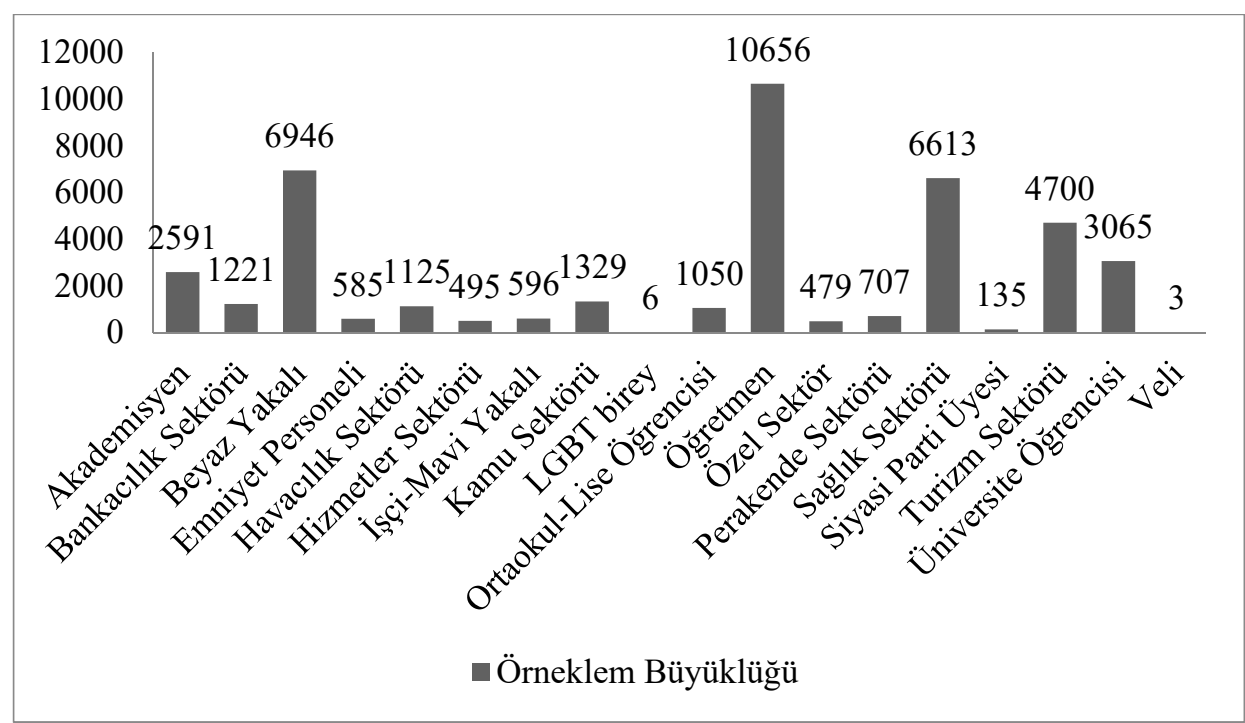

\section{Grafik 4. Lisansüstü Tezlerin Örneklem Büyüklükleri}

5.6. Ulusal Tez Merkezi Veri Tabaninda Pozitif Psikolojik Sermaye Konusu Üzerine Hazırlanan Tezler ve Bă̆ımlı Değişkenleri İlişkin Bulgular

Tablo 2'de Ulusal Tez Merkezi veri tabanından alınan Pozitif Psikolojik Sermaye konusunda hazırlanan tezlerin, bağımlı değişkenlerine ilişkin bilgiler yer almaktadır. Bu bilgiler doğrultusunda pozitif psikolojik sermaye konusu en çok iş tatmini $(n=6)$ bağımlı değişkeni ile birlikte araştırılmıştır. Ardından örgütsel bağl11ı $(n=5)$, çalışan performansı $(n=5)$, örgütsel performans yönetimi $(n=4)$, tükenmişlik $(n=4)$ ve işe adanmışlık $(n=4)$ bağımlı değişkenleri ile ele alınmıştır. Tezlerde kullanılan bağımlı değişkenlerin dağılımı Tablo 2'deki gibidir.

Tablo 2. Bă̆ımlı Değiş̧kenlere İlişkin Bulgular

\begin{tabular}{|l|c|l|c|}
\hline Bağımlı Değişken Adı & Toplam & Bağımlı Değişken Adı & Toplam \\
\hline İs Tatmini & 6 & Örgütsel Politika & 1 \\
\hline Örgütsel Bağlılık & 5 & Sapkın Örgütsel Davranış & 1 \\
\hline Çalışan Performansı & 5 & Etik Davranışlar & 1 \\
\hline Örgütsel Performans Yönetimi & 4 & İşgören Sesliliği & 1 \\
\hline Tükenmişlik & 4 & Olumlu Liderlik & 1 \\
\hline İșe Adanmışlık & 4 & Kurum Yönetimi & 1 \\
\hline I̧ten Ayrılma Niyeti & 3 & Psikolojik Sahiplenme & 1 \\
\hline Örgütsel Güven & 3 & Duygusal Bağlılık & 1 \\
\hline Örgütsel Sinizm & 3 & Örgütsel İklim & 1 \\
\hline Örgütsel Vatandaşlık & 3 & Pozitif Liderlik & 1 \\
\hline Örgütsel Destek Algısı & 2 & İş Algısı & 1 \\
\hline Yetenek Yönetimi & 2 & Rol Stresi & 1 \\
\hline Örgütsel Yabancılaşma & 2 & Çalışan Tutumu & 1 \\
\hline Örgütsel Sessizlik & 2 & İşveren Markası Oluşumu & 1 \\
\hline Yenilikçilik & 2 & Etik Liderlik & 1 \\
\hline
\end{tabular}


Pozitif Psikolojik Sermaye Çalışmaları Üzerine Bir İçerik Analizi

Tablo 2 Devamı: Bă̆ımlı Değişkenlere İlişkin Bulgular

\begin{tabular}{|l|c|l|c|}
\hline Lider Üye Etkileşimi & 2 & Psikolojik Güvenlik & 1 \\
\hline Psikolojik İyi Oluş & 2 & İlişki Ağı Kurma Yeteneği & 1 \\
\hline İş Stresi & 1 & Duygusal Tükenme & 1 \\
\hline Dindarlı & 1 & Duyarsızlaşma & 1 \\
\hline Politik Davranış & 1 & İş Sağlığı ve Güvenliği & 1 \\
\hline Yeterlilik İnanc1 & 1 & Risk Alma Eğilimi & 1 \\
\hline İsyeri Ruhsallığı & 1 & İşveren Markası & 1 \\
\hline Duygusal Zekâ & 1 & Çalışma Tutkunluğu & 1 \\
\hline Kültürel Zekâ & 1 & Otantik Liderlik & 1 \\
\hline Öğretimsel Liderlik & 1 & Şükran Müdahaleleri & 1 \\
\hline Problem Çözme Becerisi & 1 & Stresle Başa Çıkma & 1 \\
\hline Öğrenen Özerkliği Destekleme & 1 & Çalışan Dayanıklılı̆̆1 & 1 \\
\hline İş-Aile Zenginleşmesi & 1 & Benlik Saygisı & 1 \\
\hline İngilizce Öğrenme Motivasyonu & 1 & İş Talepleri & 1 \\
\hline İş Yaşam Kalitesi & 1 & İş Kaynakları & 1 \\
\hline Vizyoner Liderlik & 1 & Etkileşimci Liderlik & 1 \\
\hline Öz yeterlilik & 1 & Serbestlik Tanıyan Liderlik & 1 \\
\hline Örgüt Uyumu & 1 & Sosyal Kaytarma & 1 \\
\hline Okul Etkililiği & 1 & Dönüşümcü Liderlik & 1 \\
\hline
\end{tabular}

5.7. Ulusal Tez Merkezi Veri Tabaninda Pozitif Psikolojik Sermaye Konusu Üzerine Hazırlanan Tezler ve Bağımsız Değiş̧kenleri İlişkin Bulgular

Tablo 3'de Ulusal Tez Merkezi veri tabanından alınan Pozitif Psikolojik Sermaye konusunda hazırlanan tezlerin, bağımsız değişkenlerine ilişkin bilgiler yer almaktadır. Bu bilgiler doğrultusunda pozitif psikolojik sermaye konusu en çok cinsiyet $(\mathrm{n}=71)$ bağımsız değişkeni ile birlikte araştırılmışıtır. Ardından çalışma süresi-deneyim $(n=67)$, eğitim $(n=67)$, yaş $(n=63)$, medeni durum $(n=56)$ ve statü-unvan-pozisyon $(n=27)$ bağımsız değişkenleri ile ele alınmıştır. Tezlerde kullanılan bağımsız değişkenlere ilişkin bilgiler aşağıdaki Tablo 3'deki gibidir.

Tablo 3. Bağımsız Değişkenlere İlişkin Bulgular

\begin{tabular}{|l|c|l|c|}
\hline Bağımsız Değişken Adı & Toplam & Bağımsız Değişken Adı & Toplam \\
\hline Cinsiyet & 71 & Beden İmajı & 1 \\
\hline Çalışma Süresi-Deneyim & 67 & Öğrenim Şekli & 1 \\
\hline Eğitim & 67 & Okula Yönelik Başarı Algısı & 1 \\
\hline Yaş & 63 & Okulun Ulaşım Düzeyi & 1 \\
\hline Medeni Durum & 56 & Okuldaki Yönetici Sayısı & 1 \\
\hline Statü-Unvan-Pozisyon & 27 & Annenin Eğitim Seviyesi & 1 \\
\hline Kıdem & 24 & Bireylerin Büyüdüğü Çevre & 1 \\
\hline Gelir & 22 & Olumsuzluk Yaşama Düzeyleri & 1 \\
\hline Çalışma Alanı-Branş & 16 & Dilsel Uyarlama & 1 \\
\hline Okul Türü & 13 & Değişmezlik & 1 \\
\hline Öğretmen Sayısı & 12 & Otantik Liderlik & 1 \\
\hline Bölüm-Birim-Departman & 10 & Ülkelere Göre Farklılık & 1 \\
\hline Kurum Türü & 7 & Örgütsel Politika & 1 \\
\hline Sektör & 4 & Klimatrik Dönem & 1 \\
\hline
\end{tabular}


Tablo 3 Devamı: Bağımsız Değiş̧kenlere İlişkin Bulgular

\begin{tabular}{|c|c|c|c|}
\hline Yönetici Olup Olmama & 3 & Çalışma Düzeni & 1 \\
\hline Maaş Memnuniyeti & 3 & Eve İş Taşıma Durumu & 1 \\
\hline İş Tatmini & 3 & Aktif Spor Yapma Durumu & 1 \\
\hline Örgütsel Vatandaşlik & 3 & $\mathrm{X}$ - Y Kuşağına göre & 1 \\
\hline Psikolojik İyi Oluş & 3 & Sinav Kaygis1 & 1 \\
\hline Yaşam Doyumu & 3 & Duygusal Zekâ & 1 \\
\hline Mezun Olunan Bölüm & 3 & Vizyoner Liderlik & 1 \\
\hline Çocuk Sayısı & 3 & Mobbing & 1 \\
\hline Kişilik Özellik/Türü & 2 & Yönetici Desteği & 1 \\
\hline İl/Bölge Gelişmişliği & 2 & Çalışma Alanı & 1 \\
\hline Meslek & 2 & Lider Üye Etkileşimi & 1 \\
\hline Okuldaki Öğrenci Sayısı & 2 & Kariyer Yönetimi & 1 \\
\hline Örgüt İklimi & 2 & İktisadi Değer & 1 \\
\hline İş Aile Çatışması & 2 & Duygusal İyilik & 1 \\
\hline Dönüşümcü Liderlik & 2 & İşgören Performans1 & 1 \\
\hline Örgüte Bağl1lık & 2 & İşe Tutkunluk & 1 \\
\hline Psikiyatrik Başvuru/Tanı & 2 & Mutluluk & 1 \\
\hline Tükenmişlik & 2 & Duyguları İfade Edebilme & 1 \\
\hline Yabanc1 Dil Bilgisi & 1 & Bağlanma Stilleri & 1 \\
\hline Parti Üyelik Süresi & 1 & İş Becerikliliği & 1 \\
\hline $\begin{array}{l}\text { Parti Yönetiminde Bulunma } \\
\text { Süresi }\end{array}$ & 1 & Kaçıncı İşi & 1 \\
\hline Parti Dışında Bir İşte Çalışma & 1 & İşten Ayrılma Niyeti & 1 \\
\hline Sinifi & 1 & Dindarlık & 1 \\
\hline En Uzun Yaşadığg Yer & 1 & Stresle Başa Çıkma & 1 \\
\hline Hayatının Amacı & 1 & Hizmet Verilen Kişi Sayısı & 1 \\
\hline Hayatının Anlamı & 1 & Toplantı Say1s1 & 1 \\
\hline Görev Yap1s1 & 1 & Değer Biçimlendirme & 1 \\
\hline Benlik Saygıs1 & 1 & Duygusal Emek & 1 \\
\hline Metabolik Sendrom & 1 & & \\
\hline
\end{tabular}

\section{Sonuç}

Olumsuz davranışlar yerine olumlu davranışlara yönelimi arttıran pozitif psikolojik sermaye, kurumlarda insan kaynaklarının öneminin anlaşılması ve insanın gerçek potansiyelinin ortaya çıkarılması adına örgütsel davranış başta olmak üzere birçok alanda araştırılmaktadır. Bu araştırmayla konuya ilişkin bilgileri ortaya koymak üzere, Türkiye'de Ulusal Tez Merkezinden elde edilen pozitif psikolojik sermaye konusundaki lisansüstü tez çalışmaları, içerik analizi yöntemi ile ele alınmıştır. Tezlerden elde edilen bilgiler doğrultusunda, pozitif psikolojik sermaye konusunda hazırlanan yüksek lisans ve doktora tez çalışmalarında en çok kullanılan anahtar kelime öğretmendir. Pozitif psikolojik sermaye konusunda en fazla lisansüstü tez çalışmasının yapıldığı il İstanbul, en fazla tezin yazıldığ 1 üniversiteler Marmara Üniversitesi ve Çanakkale Üniversitesidir. Konuya ilişkin hazırlanan tezlerin büyük bir kısmı Sosyal Bilimler Enstitüsünde ve en çok ișletme alanında hazırlanmıștır. Konuya ilișkin ilk tez 2011 yılında, en çok çalışma 2019 yılında hazırlanmıştır. Çalışmalarda 
en çok kullanılan analiz yöntemleri; Cronbach Alpha değeri, korelasyon ve t testidir. Araştırma sonuçlarına göre, en büyük örneklem grubunu öğretmenler ve ardından beyaz yakalı çalışanlar oluşturmuştur. Hazırlanan tezlerde, pozitif psikolojik sermaye konusu ile en çok iş tatmini, ardından örgütsel bağlılık, çalışan performans1, örgütsel performans yönetimi, tükenmişlik ve işe adanmışlık bağımlı değişkenleri ele alınmıştır. Bağımsız değişkenlere bakıldığında; konu en çok cinsiyet bağımsız değişkeni ile birlikte araştırılmıştır. Ardından çalışma süresi-deneyim, eğitim, yaş, medeni durum ve statü-unvanpozisyon bağımsız değişkenleri ile ele alınmıştır.

Çalışmanın son sorusu olarak, pozitif psikolojik sermaye konusuna ilişkin hazırlanan lisansüstü tezlerdeki neden sonuç ilişkilerinin neler olduğunun ortaya konulması amaçlanmıştır. Bu doğrultuda çalışmalar ele alınmıştır. Atış (2020: 105) çalışmasında, pozitif psikolojik sermaye boyutlarından dayanıklılık boyutunda cinsiyete göre farklılığa ulaşmıştır. Kadın öğretmenlerin ortalamalarını erkeklere göre daha yüksek bulmuştur. Kadın öğretmenlerin eğitim konusunda erkek öğretmenlere göre güçlüklere karşı daha mücadeleci bir ruha sahip olduğunu ifade etmiştir. Koç (2019: 100), erkek hastane çalışanlarının pozitif psikolojik sermaye ortalamalarının kadın çalışanlara göre daha yüksek olduğu sonucuna ulaşmıştır. Kara (2014: 68), beyaz yakalı çalışanlar üzerine yaptığ cinsiyete göre farklılık analizinde, katılımcıların pozitif psikolojik sermaye ortalamalarında cinsiyete göre bir farklılığa ulaşamamıştır.

Şahin (2020: 4) doktora tezinde; umut, öz yeterlilik, dayanıklılık ve iyimserlik gibi dört önemli boyutu olan pozitif psikolojik sermayenin, öğretmenlerin iletişim becerileri ve kendilerini ifade edebilmeleri açısından etkili olacağını ileri sürmüştür. Dağcı (2014: 101) pozitif psikolojik sermaye konusunda eğitim alınan bölüm bazında farklılık olup olmadığına dair hazırladığ1 araştırma sonuçlarında, İlahiyat Fakültesi öğrencilerinin umut düzeylerinde farklılı̆̆a rastlamıştır. İlahiyat öğrencilerinin, İktisadi İdari Bilimler Fakültesi, Eğitim Fakültesi ve Mühendislik Fakültelerinde eğitim alan öğrencilere göre umut düzeylerinin anlamlı ölçüde yüksek olduğunu ifade etmiştir. Avşaroğlu (2017) üniversitede öğrenim gören öğrencilerin bir dönem boyunca ve haftada 3 saat aldıkları pozitif psikoloji dersiyle, dönem sonunda kişisel iyi oluş ortalamalarının yüksek bulunduğu fakat mental iyi oluş ortalamalarında anlamlı bir fark olmadığı sonucuna ulaşmıştır.

Enderoğlu (2018: 34) çalışmasında, 19-25 yıl arasındaki kıdemli çalışanların pozitif psikolojik sermaye ifadelerine yönelik ortalamalarının daha yüksek olduğunu belirtmiştir. Demirel (2020: 68) 36 yaş ve üzerinde yaş aralığında olan bireylerin psikolojik sermaye açısından 25 yaş altındakilere göre anlamlı bir farklılığa sahip olduklarına dikkat çekmiştir. Torun (2020: 63), pozitif psikolojik sermaye boyutlarından öz etkinliğin, 41 yaşından büyük olan bireylerde 31-40 yaş aralığındaki kişilere göre daha yüksek olduğu sonucuna ulaşmıştır. Yılmaz (2019: 58), hemşirelerin çalıştıkları birime göre psikolojik 
sermaye düzeylerinde farklılık olup olmadığını araştırmıştır. Sonuç olarak riskli bölümlerde hizmet veren hemşirelerin, yataklı hastaların kaldığı bölümlerde görev yapan hemşirelere göre daha iyimser bir ortalamaya sahip olduklarını ifade etmiştir.

Yiter (2019) çalışmasında bireylerin pozitif psikolojik sermaye düzeyleri arttıkça stresle başa çıkma konusunda daha başarılı olacaklarına ilişkin sonuçlara ulaşmıştır. Oruç (2015) akademisyenlerin pozitif psikolojik sermaye düzeyleri üzerine hazırladığı doktora çalışmasında, psikolojik sermaye düzeyi düşük olan akademisyenlerin psikolojik sermaye düzeyleri yüksek olan kişilere nazaran daha çok tavizci davranışta bulunma, ikiyüzlü olma ve çıkarcı davranış sergileme eğilimde oldukları sonucuna ulaşmıştır.

Orhan (2020: 112) çalışmasında, çalışanların sahip olduğu güçlü bir işveren marka algısının, işe ilişkin tutkunluklarını olumlu yönde etkileyeceğini ve bu tutkunluğun artmasında pozitif psikolojik sermayenin de aracı etkisi olduğunu ortaya koymuştur. Demirel (2020) pozitif psikolojik sermayenin iş performansı üzerine etkisini araştırmış ve pozitif yönde anlamlı bir etki olduğu sonucuna ulaşmıştır. Özata (2020: 33) yöneticilerle çalışanlar arasındaki pozitif psikolojik sermaye düzeylerinin farklılığını araştırmıştır. Araştırma sonucunda, yöneticilerin ortalamalarının yüksek olmasının, çalışanların pozitif psikolojik sermaye düzeyini olumlu etkilediği sonucuna ulaşılmıştır. Bilmez (2020) beyaz yakalı çalışanlar üzerine yaptığı çalışmasında, pozitif psikolojik sermaye alt boyutlarından iyimserlik ve dayanıklılık boyutlarının, çalışanların iş tatmin düzeylerini olumlu etkilediğini tespit etmiştir. Dilsiz (2018), öğretmenlerin örgütsel destek algılamaları ile psikolojik sermaye düzeyleri arasında düşük seviyede anlamlı bir ilişkiye rastlamıştır. Seçilmiş (2019), öğretmenlerin kurumlarına karşı uyum sağlamalarının desteklenmesi ve öz yeterlilik algılarının arttırılmasıyla, örgütsel yabancılaşmalarının azalabileceğini ifade etmiş̧ir. Aydemir (2017: 167) akademisyenlere yönelik çalışmasında, psikolojik performansı, pozitif psikolojik sermayenin anlamlı bir şekilde etkilediği ve öz yeterliliğin yabancılaşma üzerine pozitif yönde anlamlı bir etkisi olduğu sonucuna ulaşmıştır. Akdaş (2017), sağlık çalışanları örnekleminde hazırladığı çalışmasında pozitif psikoloji ile işten ayrılma niyeti ve iş stresi arasında negatif yönlü anlamlı bir ilişkiye rastlamıştır. Yani burada çalışanların pozitif psikoloji düzeyi arttıkça, işten ayrılma niyetleri ve iş stresleri azalmaktadır.

Yapılan içerik analizi sonucu, lisansüstü tezlerden elde edilen bilgiler doğrultusunda, çalışanlara pozitif psikolojik ortamın sunulmasına ilişkin gerekli şartların sağlanmasıyla; tükenmişlik, düşük motivasyon, stres, negatif duygular, işten ayrılma niyeti, yabancılaşma gibi birçok olumsuz durumun olumlu hale dönüştürebildiği sonucuna ulaşılmıştır. Birey ve örgüt açısından pozitif psikolojinin varlığı, yani yöneticilerin ve çalışanların iyimser tutumları, umut aşılamaları, kendi öz yeterliliklerine ilişkin olumlu tutumları, psikolojik dayanıklılıkları, bireysel performansları ve dolayısıyla örgütsel performansı artırabilmektedir. Örgüt içerisinde yaşanan olumsuz durumların en alt seviyeye 
indirilmesi, huzurlu bir örgüt ortamı açısından hayati önem taşımaktadır. Örgütsel huzur ortamı, yani pozitif psikolojinin örgütte varlığı, yapılan işin kalitesi ile birlikte örgütsel verimliliği de olumlu etkileyecek boyuttadır. Bu nedenle, iç ve dış müşteri memnuniyetinin önemli olduğu günümüz iş dünyasında, örgütler açısından pozitif psikoloji, maddi sermaye kaynakları kadar önemli bir sermaye olarak görülmelidir. Bu çalışmada pozitif psikolojik sermaye konusu, Türkiye'deki lisansüstü tezler kapsamında Ulusal Tez Merkezi veri tabanından elde edilen yüksek lisans ve doktora çalışmaları ile sınırlı tutulmuştur. Bundan sonra yapılacak çalışmalarda, Türkiye ile birlikte farklı ülkelerin lisansüstü çalışmalarının karşılaştırmalı olarak ele alınması önerilebilir.

\section{Kaynaklar}

Akdaş, K. (2017). Pozitif Psikolojik Sermaye, $\dot{I}_{S ̧}$ Stresi ve Işsten Ayrılma Niyeti Illişkisi: Erzurum ve Denizli Uygulamast, Yayımlanmamış Yüksek Lisans Tezi, Atatürk Üniversitesi, Sosyal Bilimler Enstitüsü, Erzurum.

Atış, D. (2020). Okul Etkililiği ve Pozitif Psikolojik Sermaye İlişkilerine İlişskin Öğretmen Görüssleri, Yayımlanmamış Doktora Tezi, Anadolu Üniversitesi, Eğitim Bilimleri Enstitüsü, Eskişehir.

Avşaroğlu, Z. (2017). Bir Dönem Boyunca Verilen Pozitif Psikoloji Dersinin Ögrrencilerin Mental Iyi Oluş ve Kişisel İyi Oluşlarına Olan Etkisinin Incelenmesi, Yayımlanmamış Yüksek Lisans Tezi, Üsküdar Üniversitesi, Sosyal Bilimler Enstitüsü, İstanbul.

Aydemir, C. (2017). İş-Aile Çatışmasının Psikolojik Performans Üzerindeki Etkisi: İşe Yabancılaşma ve Pozitif Psikolojik Sermayenin Aracı Rolü, Yayımlanmamış Doktora Tezi, Erciyes Üniversitesi, Sosyal Bilimler Enstitüsü, Kayseri.

Bilmez, F. (2020). Pozitif Psikolojik Sermayenin Alt Boyutlarının Görev

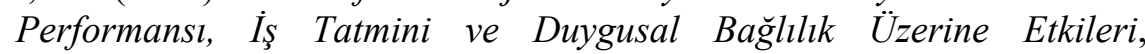
Yayımlanmamış Yüksek Lisans Tezi, Çanakkale Onsekiz Mart Üniversitesi, Lisansüstü Eğitim Enstitüsü, Çanakkale.

Cohen, L.; Manion, L.; Morrison, K. (2007). Research Methods in Education (6th ed.). New York: Routledge.

Çilingir, A. (2017). İletişim Alanında İçerik Analizi Yöntemi Kullanılarak Yapılan Yüksek Lisans ve Doktora Tezleri Üzerine Bir İnceleme, Erciyes Iletişim, 5 (1), 148-160.

Dağc1, A. (2014). Pozitif Psikoloji Bağlamında Umudun Dindarlıkla İliş̧kisi, Yayımlanmamış Yüksek Lisans Tezi, Necmettin Erbakan Üniversitesi Sosyal Bilimler Enstitüsü, Felsefe ve Din Bilimleri Anabilim Dal, Konya.

Demirel, S. (2020). Pozitif Psikolojik Sermayenin Işs Performansina Etkisi: Av Sanayii Çalı̧̧anları Üzerine Bir Araştırma, Yayımlanmamış Yüksek 
Lisans Tezi, Burdur Mehmet Akif Ersoy Üniversitesi, Sosyal Bilimler Enstitüsü, Burdur.

Dilsiz, F. (2018). Öğretmenlerin Örgütsel Destek Algıları ile Pozitif Psikolojik Sermaye Düzeyleri Arasındaki İlişki, Yayımlanmamış Yüksek Lisans Tezi, Uşak Üniversitesi, Sosyal Bilimler Enstitüsü, Uşak.

Enderoğlu, E. G. (2018). Bilişim Sektöründe Çalışan Bireylerde Pozitif Psikolojik Sermaye ile Tükenmişlik Belirtileri Arasındaki İlişkinin Incelenmesi, Yayımlanmamış Yüksek Lisans Tezi, Haliç Üniversitesi, Sosyal Bilimler Enstitüsü, İstanbul.

Kara, U. A. (2014). Pozitif Psikolojik Sermaye ile Bireysel Performans Ilişskisi: Tarım Kredi Kooperatifleri Merkez Birliği Örneği, Yayımlanmamış Yüksek Lisans Tezi, Gazi Üniversitesi, Sosyal Bilimler Enstitüsü, İşletme Anabilim Dalı, Ankara.

Koç, A. D. (2019). Pozitif Psikolojik Sermaye ile Duygusal Emek Arasındaki İlişkinin Incelenmesi: Hastane Çalışanlar Üzerine Bir Araştırma, Yayımlanmamış Doktora Tezi, Süleyman Demirel Üniversitesi, Sosyal Bilimler Enstitüsü, Isparta.

Linley, A. P.; Joseph, S. H. S.; Wood, A. M., (2006). "Positive Psychology: Past, Present and (Possible) Future", The Journal of Positive Psychology, 1 (1), 3-16.

Luthans, F.; Youssef, C. M.; Avolio, B. J. (2007). Psychological Capital: Developing The Human Competitive Edge. Oxford: Oxford University Press.

Maslow, A. (1954). Motivation and Personality. New York: Harper \& Row, Publishers, Inc.

Orhan, E. (2020). İşveren Marka Algısının Çalışmaya Tutkunluk Üzerine Etkisi Ve Pozitif Psikolojik Sermayenin Düzenleyici Rolü, Yayımlanmamış Yüksek Lisans Tezi, Bilecik Şeyh Edebali Üniversitesi Sosyal Bilimler Enstitüsü, Bilecik.

Oruç, E. (2015). Pozitif Psikolojik Sermayenin Politik Davranışlara Etkisi: Akademisyenler Üzerine Bir Araştırma, Yayımlanmamış Doktora Tezi, Sakarya Üniversitesi, Sosyal Bilimleri Enstitüsü, Sakarya.

Özata, A. (2020). Yöneticinin Pozitif Psikolojik Sermayesinin Astlarının Pozitif Psikolojik Sermaye Özelliklerine Etkisi: Otomotiv Sektöründe Bir Araştırma, Yayımlanmamış Yüksek Lisans Tezi, Bahçeşehir Üniversitesi, Sosyal Bilimler Enstitüsü, İstanbul.

Sağır, M. (2020). Psikolojik Sermaye, M.Ş. Şimşek, A. Çelik, T. Akgemci ve A. Diken içinde, Örgütsel Davranış ve Yönetim Psikolojisi, 563-574, Konya, Eğitim Yayınevi.

Şahin, G. (2020). Öğretmenlerin Kişilik Özellikleri ile Atılganlıkları Arasında Ilisşkide Pozitif Psikolojik Sermayelerinin Aracı Rolü, Yayımlanmamış Doktora Tezi, Hacettepe Üniversitesi, Eğitim Bilimleri Enstitüsü, Ankara. 
Pozitif Psikolojik Sermaye Çalışmaları Üzerine Bir İçerik Analizi

Torun, F. (2020). Pozitif Psikolojik Sermaye ve Örgüt İklimi Arasındaki İlişki, Yayımlanmamış Yüksek Lisans Tezi, İstanbul Ticaret Üniversitesi Sosyal Bilimler Enstitüsü, İstanbul.

Tösten, R. (2015). Öğretmenlerin Pozitif Psikolojik Sermayelerine İlişki Algılarının Incelenmesi, Yayımlanmamış Doktora Tezi, Gaziantep Üniversitesi, Eğitim Bilimleri Enstitüsü, Gaziantep.

Yılmaz, M. (2019). Pozitif Psikolojik Sermaye ile Mesleki Tükenmişlik Arasındaki İlişkinin Analizi: Hemşireler Üzerinde Yapılan Bir Araştırma, Yayımlanmamış Yüksek Lisans Tezi, Nişantaşı Üniversitesi, Sosyal Bilimleri Enstitüsü, İstanbul.

Yiter, G. (2019). Pozitif Psikolojik Sermaye ve Stresle Başa Çıkma Stratejileri Arasındaki İlişkinin İncelenmesi (Adana Kamu Kurumu Örneği), Yayımlanmamış Yüksek Lisans Tezi, Çağ Üniversitesi, Sosyal Bilimler Enstitüsü, Mersin. 